\title{
Abstracts
}

Werner Distler/Sarah Riese

The Other Side of the Coin: Intervention and Resistance in Bosnia-Herzegovina and Kosovo

ZeFKo Vol. 2 (2013), No. 2, pp. 177-208

Interventions aim for peace-building, state-building and democratization. In those processes, intervened societies are confronted with international preferences. International actors are neither democratically legitimized by the intervened society nor accountable to the citizenry. Institutions for legitimate political conflict settlement between international and domestic actors are missing. Rather, political resistance is often delegitimized as spoiling. Under these conditions, we argue that political resistance is an expectable consequence of long-term interventions. By drawing on examples of the party Savez Nezavisnih Socijaldemokrata from Bosnia and the movement VETËVENDOSJE! in Kosovo, we illustrate how strongly both organizations identify themselves as agents of resistance. Both organizations could only evolve successfully under conditions of intervention. Instead of delegitimizing resistance and ignoring the relation between intervention and resistance, we need to understand interventions as deeply political processes which require political and institutional forms of conflict regulation.

Keywords: intervention, state-building, resistance, conflict regulation, Bosnia-Herzegovina, Kosovo

\section{Ekkart Zimmermann}

\section{The »Arab Spring« in Comparative Revolutionary Analysis}

\section{ZeFKo Vol. 2 (2013), No. 2, pp. 209-245}

Causes, paths and interim results of the $»$ Arab Spring « are discussed from the perspective of comparative revolutionary analysis. One has to distinguish revolutionary situations, with a multitude of conflict forms, from revolutionary outcomes. One should also consider the options for development granted by different forms of political authority. Sultanist rule here allows for only highly limited perspectives. Such a form of political authority is focused only on the ruler and his entourage. There is no developing of persistent institutions that would allow for smooth political change and the provision of public goods, which is characteristic of democratic order. In assessing the chances of transformation and possible scenarios the analysis draws on numerous other theoretical elements. Population pressures by an extremely 
young and mostly unemployed or underemployed population and the lack of a regional power are two of the crucial burdens. Further one finds persistent culturalreligious cleavages. The Arab monarchies from Morocco to Saudi-Arabia have reacted with very limited political concessions and welfare payments to buy off protest sentiments. Thus far they could avoid regime failure as occurred to the more Sultanist regimes in Libya and Syria.

Keywords: political violence, rebellion, sultanism, political order, comparative revolutionary analysis

\section{Johanna Ray Vollhardt/J. Christopher Cohrs}

\section{Current Social Psychological Contributions to Peace and Conflict Studies} ZeFKo Vol. 2 (2013), No. 2, pp. 246-278

This article reviews current social psychological research on issues related to peace and conflict. Building on a content analysis of social psychological peace research (Vollhardt/Bilali 2008), we review articles published between 2008 and 2012 in journals representing mainstream social psychology: »Journal of Personality and Social Psychology«, »Personality and Social Psychology Bulletin«, »European Journal of Social Psychology«, and »Basic and Applied Social Psychology«. Current trends that are relevant to Peace and Conflict Studies are identified and discussed. We also discuss the role of liberation psychology and other more critical directions within psychology in increasing the potential of social psychological research to contribute to interdisciplinary Peace and Conflict Studies. This includes a stronger internationalization of the field, increased use of field research, cooperation with NGOs, a greater contextualization of research questions and more consideration of macro-level influences. Finally, we briefly introduce social psychological peace research and relevant organizational structures in Germany.

Keywords: social psychology, peace psychology, social psychological peace research, contextual psychology, liberation psychology 